\title{
Draining out the Colours: an Interview with Patrick McCabe
}

\author{
Mathias Lebargy \\ Université de Caen Basse-Normandie, France
}

Copyright (c) 2013 by Mathias Lebargy. This text may be archived and redistributed both in electronic form and in hard copy, provided that the author and journal are properly cited and no fee is charged for access.

\begin{abstract}
In this interview Patrick McCabe sheds some light on his sources of inspiration and creative process as he talks about the evolution of his hometown, the stage adaptation of The Butcher Boy, and some major influences, such as the Gothic tradition. The growing importance of the latter turns his fiction into something darker and more sinister; a realm in which humour is non-existent, and evil omnipresent.
\end{abstract}

Key Words. Patrick McCabe, contemporary Irish literature, Gothic, adaptation, religion, story-telling, social changes.

Resumen. En esta entrevista Patrick McCabe arroja luz sobre algunas de sus fuentes de inspiración y sobre su proceso creativo a medida que habla sobre la evolución de su pueblo natal, la adaptación teatral de The Butcher Boy, e influencias relevantes como la tradición gótica. La creciente importancia de ésta ha hecho su ficción más sombría y siniestra, un terreno en el que ya no cabe el humor y el mal es omnipresente.

Palabras clave. Patrick McCabe, literatura irlandesa contemporánea, tradición gótica, adaptación, religión, contar historias, cambios sociales.

This interview with Irish author Patrick McCabe took place after the publication of Winterwood (2006), when The Revenant (2007), McCabe's fourth play, was performed at the Galway Arts Festival in July 2007. Comfortably seated in his living room, McCabe sheds some light on his inspiration and creative process as he talks about the evolution of his hometown, Clones (namely the changes it underwent during the Troubles). He explains here how he first started to write for the stage, when he adapted his highly acclaimed novel The Butcher Boy (1992) into the play Frank Pig Says Hello (1998). Reflecting on the process of adapting one's own work, McCabe brings to the fore the power of rewriting that shapes his literary project, be it the rewriting of some of his earlier pieces, the influence of Technicolor movies by Sam Fuller, or, more relevant to his later fiction, the influence of the Gothic tradition. A professional writer since 1992, McCabe keeps with the tradition of storytelling in which he was immersed from a very young age. Interestingly, he admits the growing importance of the supernatural in his work, as his "small town" trilogy testifies. This trilogy, which began with Winterwood, includes The Holy City' (2009), and was completed with the publication of The Stray Sod Country in 2010. Some of McCabe's remarks on priests and demons foretell the central theme of his latest novel. 
Mathias Lebargy: I have some questions ready but I'm sure others will come progressively.

McCabe: Yeah, yeah... Just feel free. Sometimes you learn more from a casual conversation, as things arise... It's better because... I'd probably say things that mightn't have occurred to you to ask... But what you might find interesting is... this block here. There are twelve houses, a red-brick terrace... And the world of Frank Pig Says Hello, which is a childhood world really... Out here, it would have been full of children, all day, every day, just playing. That's completely gone now. Just as if it never existed. There used to be a huge, big railway, big colonial-style building, granite... There was constant movement and traffic over there: people coming and going, engineers, workmen of all kinds... Overnight that disappeared. And what you're seeing now is a world that has vanished... It was a major railway junction, which served Donegal, Belfast, Dublin. Maybe, there would have been a hundred skilled workers from the town, so that was major industry for a small place of 2,000 people. They all lost their jobs overnight. They all disappeared. And they tried many industries after that, but none of them really succeeded. They tried all sorts of things: the shirt factory, the meat factory... Some of them worked, some of them didn't.

\section{ML: So there was a meat factory here?}

McCabe: There was yes. There still is, but it's not as busy as it was. That would have provided a lot of employment in the 70s. But what really ended it was... when the conflict across the border erupted. And because this is the bottom end of Ulster, all the roads that led to Ulster were all blocked off. So, the people who used to come from the North to visit the bars and go to the cinema, they all stopped.

\section{ML: There was a picture house as well then?}

McCabe: There were also lots of cinemas... They're all gone. So it's almost like a tale of a vanishing community... In the 70s you had all these people coming to visit and then the bombs started to go off and they stopped coming and they never came back. People make drills of habits... And it's as if this town hadn't moved on enough, like the hotel for example... When I was a boy, it was very stylish. The owner used to wear a carnation in his button hole. And he was a brandy drinker, drinking brandy all day... A bon vivant, a big food man... He liked his wines! At the time, you didn't sell wine much in Ireland, but he was like that. But then he died, and that coincided with the vanishing...

\section{ML: And no one took on?}

McCabe: Nobody took on the bar as it were, so it was sort of sliding down. It was about style you know, he had style. Because of the railways people were more outward-looking, they were open to ideas. People coming and going, not like now. At that time it was forward-thinking and people would have travelled you see, not like now. And, what's going to happen is there'll never be any industry here again. But... They are now linking a canal which comes from Ulster right down the South and that's going to be opening up, which means that in 10 or 15 years time, you'll have a leisure industry here, a kind of waterway sort of community. But again, it will simply be a quiet little town with no real, separate, distinct identity. It will be a leisure town, interesting up to a point. But as a place to visit, not linger in. So in a way its time is gone. The world that I'm writing about, ...

ML: So you really think there won't be any second chance for the town?

McCabe: Well, the families are much smaller now. I mean, this is a case in point. There are a number of young families down here now, but they only have one or two children in them. So the world that I write about, which is a world of noise and clamour and excitement... an interacting community... That will never happen again. Because Ireland was very strange in that, even though it's a Catholic country, the families were huge, and they couldn't afford to feed them because they were poor. So the kids were out all day every day, and you know, wearing shoddy enough clothes. But they were tremendously vital. A huge vivacity...

\section{ML: With a real link between people as well.}

McCabe: Oh yes, all the time. Good and bad. Not all good. That's no longer the case. It might be interesting to compare provincial French villages to Irish villages, because I have a friend who lives in Languedoc; the French are very good to him at preserving traditions. This 
may be true or may not be true, but he says that compared to Ireland, which takes everything American, which takes everything that comes in, which consumes like a slavering animal, without thinking if this is good or bad... I mean, in France you have restrictions on the American movies, don't they? If you consider all these things, is it good for France? That's the first thing. I won't say if it's right or wrong. But Ireland hasn't any of those. So what it means is that you get everything all at once. You turn from a very quiet little place, a story book, to this bustling, crazy-... And even religion doesn't matter. Of course officially it matters. It's a social habit. But there is no spirituality, if there ever was... It seems that in France, when you talk about Notre-Dame, people speak about the architecture. There's a link, people love it, they're very proud of it. I don't think you'd have the same conversation here. Possibly for historical reasons.

ML: I'd say that spirituality is vanishing in France as well.

McCabe: Well, that's interesting!

ML: But from the inside it's difficult to say whether we're losing a kind of identity really. It might be easier for your friend, who can watch the French community from an outside perspective.

McCabe: Well it's just the same for you here. Because you'd see it more clearly that we might.

ML: I knew your work was influenced by Clones and small towns, but I hadn't realised it was such a strong influence.

McCabe: Yeah. It is really. Really. I've been away for many years and I came back three or four years ago. And... people don't know why I have come back, why I am living here.

ML: That's exactly what the women from the hotel asked me yesterday. When I told them you were living in Clones, they wondered why you had come back...

McCabe: Well, to be honest, writers need very quiet places to write, you know. I don't come back for romantic reasons... If it's going to be a quiet place; it might as well be a quiet place. It's in the blood. I mean, where would I find another place with which I'd have such an extraordinary kind of link, for better or worse? So, it would be better to go away altogether, rather than live somewhere else in Ireland. It would be better to live in Caen, or to live in New York, to live in Baghdad... So I was kind of very happy when I did. I had no expectations. I knew pretty much it could be very, very quiet. Almost like deathly quiet sometimes.

\section{ML: Was Sligo too busy for your liking?}

McCabe: No, no, my children were around there. They're both grown up now. One is in Thailand, the other... she lives in Sligo still. It was a perfect size, and you know, the story is not all about me. It was important for them... to grow up. You know I haven't expected to come here... They think it's eh... [laughs] Why bring kids here, you know? But... they come and visit. They don't stay very long.

ML: I have some questions about your plays. Maybe we can start with them?

McCabe: Sure, go ahead.

ML: What attracted you to theatre? I'd like to know how you got the idea to write plays.

McCabe: Possibly, the link with Joe O'Byrne is important there. He had worked in Berlin, mainly in the German expressionist strain. And he once asked me to write a play for the company he ran at the time, which was called Co-motion Theatre Company. I liked their work a lot. I liked the free form visual dance-style of it, and it wasn't exclusively verbal... Joe O'Byrne was a great designing eye... The eye of the designer, composition, visual style... And loads of work of the body, which is softly used in the Irish theatre. There's too much talk, not much physicality. So when I began to write The Butcher Boy, I had always seen the visual aspect. The character of The Butcher Boy is very physical, coming around, and moving. Always kind of alert, but also strange. It was all physical in my mind. So it seemed the perfect way to do it, and I wrote it that way. Mostly in dialogue, with very little stage directions, which O'Byrne provided. Simply, it would be interesting for one to know what the relationship I had with the director was. I knew I had to do that. If it was with another director, I wouldn't have written the play. And that continued then. I did another play called Loco 
County Lonesome, and then The Dead School, and now The Revenant. So that's four plays I've done. If you look at them all, there's a kind of sequence fluency, that is visual style.

\section{ML: As for The Dead School, you wanted to adapt it to the stage as well?}

McCabe: Yes, I suggested that. I thought we should work together again. We developed the script together, we work-shopped it and talked about it two or three days when we did it. And he brought trompe l'oeil. That was his idea. It was astounding! It's a pity it never came back because it was mind-blowing what he did with that: faces appearing, doors opening... Commedia dell'arte, really. That was very successful for one run, and I was very happy with it. It was a very difficult book to adapt though, because you have two strong characters. To give them both equal stage time... It could become a little bit formulaic, you know. But the visual-, sumptuousness of it...The texture of it was beautiful.

ML: You have adapted The Butcher Boy and The Dead School to the stage, as well as The Butcher Boy, Breakfast on Pluto, and, to a certain extent, Emerald Germs of Ireland (adapted to the screen). What is it that draws you to the adaptation process? It seems to me that your work is one continuous rewriting scheme...

McCabe: Yes, I understand. Well I think that all I do is like one long book. Right from Frank Pig, right now, right on through... it's like one long, big story, chopped up at different things. Chopped up into a novel, chopped up into a little bit from a play... But they're all intertwined...

ML: When I read Music On Clinton Street, it occurred to me that it features all the elements that you developed in depth later.

McCabe: They're all there yes. It's interesting because it's like setting out as a young man... "These are all the things I have to do. Now how would I do it?" It's only useful from that point of view because it's not a technically good book. But from the point of view of a researcher, it would be really interesting, because, as you say, every little thing is already there.
ML: Yes, it's all there. Do you know why you are always so interested in developing these same elements?

McCabe: Well, that's probably true of nearly every writer. I think of James Joyce, it's certainly true of him. It's true of Bob Dylan, his relationship with women, and all that. You know, it's a constant kind of reinvestigation of one's psyche and I think there are only four of five themes that any writer has, and once you have moved away from it your work can collapse. For example, you take Seamus Heaney and his relationship with the land and history. Sometimes it's not that interesting when he moves away from that, you know. Most writers or any authors are obsessed in one way or another. Why do they do it? Well they do it because they want to release the obsessions somewhere out, or to share with people to re-make the world in a way that makes sense. And I've never questioned the way I operated because I've done so much reading when I was a kid. I thought this happens again and again. Whether Flaubert or Nabokov or James Joyce... It's the same pattern all the time. Well, I'd say it's the same in music, and it's the same in most visual arts...

ML: In Frank Pig Says Hello, one major element from the novel has disappeared. I'm thinking of the scene when Frank is abused by Father Sullivan in the institute. Can you tell us why you decided to erase it from the play?

McCabe: I didn't decide to erase it, it must have done something like disrupt the rhythm or something. That's perhaps what happened, but I didn't consciously leave it out. I didn't mean to. To include it would have interrupted a sequence of events... It would be an architecture thing more than a decision. I think you could have left it in and it wouldn't have damaged anything. But at the time I thought "I want this all to happen in 90 minutes, so I want it to be fast, like a circus tumbler"... There are a number of other elements that were left out. For example, his relationship with Mrs Nugent, it's a sort of psychological relationship when he breaks into the house... That's not explored in the play, because it would be too much to ask the journey. It could interrupt the flow of it and go interior when it should be external. All 
that's in the novel, and again, because I was working in the framework of Commedia dell'arte, I wanted to keep that sort of rhythm going.

ML: When I worked on the scripts, the one published by Methuen and the one used for the first performances directed by Joe O'Byrne, I noticed some differences in the way the sentences were built. For example words located at the end of a sentence were put at the beginning of that sentence, or vice versa. It seemed to me that you were obsessed with rhythm...

McCabe: Oh yes, rhythm in everything... The language in everything I write has a certain rhythm about it. And unless that rhythm is right, the book is wrong. That's how I work it. It's like music, really.

ML: You have just spoken about the scene in which Piglet breaks into Mrs Nugent's house. In the play, we hear "We are the daytime ghosts of Nugent's house", yet, this isn't in the published version...

McCabe: Oh, really?

ML: Yes. So I wondered whether that change was made by Joe O'Byrne, or by you. I may have the wrong script... But it's not in the Methuen version.

McCabe: Well that's unfortunate because it should be there. Such things happen sometimes. The script they got was either the second last version, or... I don't know...

ML: In the Methuen version, the voices that appear when Piglet breaks into the house are more suggestive. Without the line "We're the daytime ghosts", the audience have to guess that what they're hearing are only voices in Piglet's head, not real characters.

McCabe: Well... I don't know which one is better now. I'd have to see it again... Whether to suggest it, or to state it... Which one do you prefer?

ML: I prefer the suggestion.

McCabe: You're probably right... Yeah, don't say it.

ML: I first thought that the line "We're the daytime ghosts..." appeared in the first run in 1992, and that you had erased it to make it more suggestive. But perhaps I'm wrong.
McCabe: It might have disappeared in rehearsal, but I can't answer because I can't remember... It probably was erased for that purpose, most likely by Joe than by me, in that it was overstatement.

ML: I worked on both versions of the script (the one used by Joe O'Byrne, and the one that was published by Methuen), and the impression I had was that you were more suggestive in the published version (which was released some years after the first performance in 1992).

McCabe: Well it may be the final version they have then... The more suggestive, the better I think.

ML: What struck me when I saw your play, The Revenant (produced in 2007), was that paedophilia and abuse are major elements. Yet, these are not developed in Frank Pig Says Hello (first produced in 1992). Were you trying to protect the audience? It was your first show, after all...

McCabe: It's also the fact that in recent times it has become a huge thing. And it struck me that the education system - because I went to a boarding school - , that the people who were appearing in courtrooms, well they were people who were warning us against monsters. These were the people who were warning us as boys to beware of the devil, to beware of women... Yet, all the time, they were wrestling with their own demons. And in fact you could argue that they were the demon, except they are not demons, you know what I mean, they are just people who get damaged... So it became a kind of interesting thing for me to deal with these characters. I mean the priest was a huge thing in the Irish life of those days, a figure of respectability, of authority, all these things... Now you could say that the priest is the devil, and people would believe it. So, because it was common, and because The Revenant was moving into this new landscape, it seemed a natural development from the world of Frank Pig when you couldn't mention it simply because the people didn't even knew the word. Now you can mention it.

ML: People may have been shocked as well.

McCabe: They'd certainly have been shocked, oh yeah. But that wouldn't have scared me or anything. The only reason I left it out is because 
I don't like shock tactics. It wouldn't be because I'd have been afraid to shock. It would have been: "Would it serve the purpose of the play to shock?"

ML: Can you remember if the readers were shocked when The Butcher Boy was published?

McCabe: Well, I got a letter from a 90-year-old nun who used to teach me. She said it was the funniest book she'd ever read... And you have to remember the true nature of people. People won't be shocked if they think they aren't to be shocked. You know, if they see themselves as respectable people in a particular period of history. Now you could have an orgy in that street, nobody'd be shocked. Nobody would be remotely shocked. What would really shock them would be "I intend to get married and I intend to stay married for the rest of my life. I intend to go to Mass every day of the week, I intend to be good..." That would shock people if you'd really believe it. That was current at the time, people would buy it. But it does the back of the nature of spirituality. At that time, the Church was beginning to collapse. The foundations were beginning to rock anyway, you know. It was only a matter of a couple of years after that.

ML: Abuse comes again in Winterwood. But it has nothing to do with priests in this book, it's incest.

McCabe: Well, at that time you could pick up a newspaper in Ireland and... It was like a huge thing, a kind of taboo that came up out of the world of the $60 \mathrm{~s}$ and 70s. And again, if I'm moving in that strange modern world that has links with the past, I don't think these subjects are very shocking.

ML: I'm not saying they are shocking. I just wondered why it's a major element in Winterwood, whereas it isn't in The Butcher Boy. In The Butcher Boy, it doesn't damage the boy as much as it does the journalist in Winterwood.

McCabe: It doesn't really damage him at all in a sense. What really damages him, is love going away. He can get over anything, but he can't get over that. [...] Winterwood is part of what is a kind of trilogy, which kind of started with Winterwood. And now I've done another book, which carries that on... That's not so much abuse, but a world of secrets, like a world of small town provincial secrets which contains appalling horrors under the cover of ordinariness or maybe even simplicity. It is set against a landscape of no religion. And before it was everything religion, there were sacré cœurs everywhere... Now it's a blasted landscape. So now the colour of everything has changed. The colour of the prose that we say... Like, The Revenant is the colour of ash. It's the Gothic grey. And that's exactly the colour of Winterwood. Now all the colours are draining out. When you think of Frank Pig, it's orange, it's crimson, acid yellows and all this carnival burlesque. Now I start to slowly but surely take away all these colours, and then you're left with a kind of X-ray photograph, with no god, with no community... Get back to Beckett really, almost. So, if the paedophile thing was there in the book to begin with because there it was in life, it's only reflecting the growth, the trajectory of the society. The second book is even starker, so I don't know what the third book's going to be like... You'll just have blank pages maybe... [laughs]

ML: That's how I feel... The Butcher Boy ends quite happily for Francie...

McCabe: Well, I thought that was wrong, that's why I wrote The Revenant.

ML: Because Francie finds a friend to hack the ice, it ends happily. Frank Pig Says Hello is a bit darker because the sky is no longer orange. And in The Revenant, the sky is grey. So it's getting darker and darker.

McCabe: Oh yeah, completely dark, no compromise. With no humour to help you along.

ML: The women I met yesterday told me the actor is a local man.

McCabe: He's from this town, yes.

\section{ML: Did you choose him yourself?}

McCabe: I wrote it for him. I wrote it for him, really. Because we grow up together, he knows the voice, he knows the world... And he's a photographer. We were shooting some photographs, and I said "I want grey, I want grey... Get all the grey, put it against the new town, and see what we get..." And then I wrote the play. [...] 
ML: Only The Butcher Boy was translated into French.

McCabe: Le Garçon Boucher, yes.

\section{ML : Do you know why?}

McCabe: It could be something to do with the agents, it could be something to do with availability of editors... The editor that picked that one was a nephew of Vladimir Nabokov. So, sometimes if you have someone working on your behalf, be it in Germany, or Poland, or anywhere, you will sell books. If you haven't, then you won't. It's really got to do with commerce, really. If the books are available, fine. If they're not, you slip out of the loop, then you come back in. The period you're talking about, everyone was interested in Irish writers. Every time you picked up newspapers, "Dermot Bolger, Roddy Doyle, Patrick McCabe..." I've got very little in common with those writers, except the fact that we're professional writers. Now, that kind of Ireland... it was trendy at that time, you know: U2, Sinead O'Connor, blah blah blah... But that passes. And then, some paper names survive, some others don't. It's not like an Irish football team, you know. It made me feel uncomfortable anyway, but, eh... I think after Winterwood it's very strange, because I used to be taken much more seriously then. Almost as if with the humour people thought "all this guy is is a kind of a frivolous writer or something, he's too funny". But when I take out the humour simply, there's some academic interest, you know. But I'd say it's to do with the availability of the books, and the presence in the country. Like, for example, John McGahern used to go to France a lot, he used to meet people, he was invited to many places. And I haven't been that much in France. [...]

ML: I have another question about leitmotivs. You said writers write about their obsessions. You use a couple of leitmotivs from one novel to another, but you also develop sets of leitmotivs that are specific to one novel. Like the colour blue and the chocolate bar in Winterwood, or the orange sky in The Butcher Boy. I'm wondering if repetitions and leitmotivs are not precisely one of your original features...

McCabe: Well, repetitions and leitmotivs are a narrative trick to some extent. Like plot, I like to keep the story advancing. While I'm interested in style, I also think it's good to tell a story and to keep people innocent, and to surprise them, and to reverse anticipation. And that's been around since the Greek times. You think you're getting one thing, but the author is out to something behind your back. So what he's doing, I' $m$ not quite sure. So, giving a little bit of information, then retracting it, then giving a little more the next time... It seems to me to be a good narrative style in the sense that, in the story-telling world that I grew up in, there used to be a lot of mischief. Mischief, you know, people weren't telling the truth. You know, the feature of the Irish Catholic mind, it's "Are they reliable?" [...] In the 60s and 70 s, I remember seeing an old guy that we don't see anymore, and a French or a German comes to him and asks him a question, and the guy made a big speech, "oh you do this, you do that"... And by the time he had finished, the tourist was exhausted. "That's not what I asked him!" So it was that old rural Irish voice; a rural voice, not a city voice. So it's kind of natural to me, having heard all these rhythms, to mimic them. Because I was a natural mimic as a child, it fits me like a glove that kind of voice, that narrative style.

ML: In Winterwood repetitions add a kind of anxiety, like a feeling of uncanniness.

McCabe: Well, yes... Sure... It's the first book I've ever drawn almost exclusively from the Gothic tradition, you know... Real Gothic like Le Fanu, or Bram Stoker... "I arrived at the castle late at night and..." And then something dreadful is going to happen and then it doesn't, it goes back to normal... So that's directly drawn from the supernatural fictions. But also when you get older, you give serious consideration to the supernatural. In a way, when you're younger, you're too busy in the business of breeding children, about running small practical things like their education, their welfare and so on... and the fun you have with your children. You're too busy. But when the children are gone, then, ooooh... [laughs]

ML: Winterwood definitely was a success. I wonder whether because Winterwood could be labelled as Gothic, it was then easier for journalists to appreciate the work...

McCabe: Well it's kind of... It is a pity, because... 
the book before that, which was called Call Me the Breeze... In a way, it's a far more complicated book. It's about the nature of art, it's about... But nobody saw it as that. They saw it as difficult, entertaining, too long, funny, but too funny... They didn't like it. [...]

ML: Critics have used the term "Bog Gothic" for your previous works, a term with which you do not agree...

McCabe: I thought it was inaccurate. Probably Winterwood is a Gothic book, but it's pretty open in many ways anyway: a lot of it is in the city, the bog world is not even there... The Bog Gothic term was a journalistic thing. It was just one guy that came up with it, but... if you examine The Butcher Boy, which is the book to which it was applied mostly, it's much closer to Technicolor movies... and movies by Sam Fuller... Blasts of colour, big sweeps... Gothic is different. Gothic is strange and sinister, and intimate. And The Butcher Boy is not, it's a big splash... I said a much more accurate term might be the "social fantastic". I thought I wanted to replace Bog Gothic with social fantastic. Certainly fantastic, ordinary fantastic, next-to-ordinary fantastic... anything but Bog Gothic. But now, I've no problem with Gothic. But again it's a catchall journalistic term. It's not like an academic investigation. [...]

ML: There is another frequent element I would like to talk about. I couldn't find any kind of explanation of the presence of snow in your works. In most of your novels, something happens during snow-time.

McCabe: Does it?

ML: Yes. So I wondered why. I know that snow is casual and is not an extraordinary phenomenon. Yet $I$ wondered if there was any particular explanation to that.

McCabe: What happens in snow?

ML: For example, in Emerald Germs of Ireland, Pat finds his tin soldier in the snow that covers the backyard. In The Butcher Boy, Francie leaves the house after Christmas, and there's snow as well. In Winterwood, there's snow too, in the park or at the very end of the book.

McCabe: Well, the little tin soldier I found in snow, so... I suppose in a place like this, what made a small place interesting is a sense of wonder. Everything was a wonder, because nothing much happened. I mean, in the Terrace, when a aeroplane passed, there were people standing and looking at it. So, what could be more wondrous than snow? When I was a kid, I was fascinated by comic book characters. Like Ruppert Bear... He'd always seemed to be throwing snowballs! These are all comic book characters, and there's a lot of snow.

\section{ML: From childhood}

McCabe: Oh yeah!

\section{ML: It may have influenced your works.}

McCabe: Oh it did, yes. That stories happen in snow time... You know, it's a nice world, for good things can happen. But usually what happens in anything I write is that, eh... it's happy you think, and then it goes wrong [laughs]. That's probably linked to my own childhood in the way that just when you think everything couldn't get any better, it goes horribly wrong. So I suppose it's probably the heartbeat of the work in that... Why does it always happen? Just as it does in life! Well it doesn't happen with the regularity I insist on, that's the difference! But snow, and fire apparently, that's another one that keeps happening up... I think a German critic told me that, but I haven't investigated myself. But sure enough it is true. There seems to be fire everywhere in my books.

ML: When you speak about snow, it's a wonderful world. Yet in your novels, it's not so wonderful. For example Francie leaves, and then his mother commits suicide...

McCabe: Yes... snow is something like a glimpse... Snow represents some kind of a glimpse of the way it should be..., but isn't!

\section{Works Cited}

McCabe, Patrick. 1992. The Butcher Boy. London: Picador.

1998. Frank Pig Says Hello, in Far From the Land. Contemporary Irish Plays. London: Methuen Drama. First performance during the 1992 Dublin Theatre Festival, directed by Joe O'Byrne. 
McCabe, Patrick. 2006. Winterwood. New York: Bloomsbury.

2007. The Revenant. Directed by Joe O'Byrne, first performance on 16 July 2007 during the Galway Arts Festival.

2009. The Holy City. New York: Bloomsbury.

2010. The Stray Sod Country. New York: Bloomsbury.

Received $18^{\text {th }}$ April 2012 Last version $17^{\text {th }}$ July 2012

Mathias Lebargy is a junior lecturer in the Department of English at the University of Caen BasseNormandie (France), where he completed his PhD in Irish and Anglo-Saxon Literature. His research includes a doctoral thesis on the writings of madness in the novels of contemporary Irish author Patrick McCabe, as well as four articles on the works of this same author, focusing on music, stage and cinematic adaptations, and the representation of time. 